New discoveries of tetrapods (ichthyostegid-like and whatcheeriid-like) in the Famennian (Late Devonian) localities of Strud and Becco (Belgium)

\title{
SÉBASTIEN OLIVE ${ }^{1,2}$, PER E. AHLBERG ${ }^{3}$, VINCENT N. PERNÈGRE ${ }^{4}$, ÉDOUARD POTY ${ }^{2}$, ÉTIENNE STEURBAUT ${ }^{1,5}$ \& GAËL CLÉMENT ${ }^{6}$
}

${ }^{1}$ OD Earth and History of Life, Royal Belgian Institute of Natural Sciences, Rue Vautier 29, 1000 Brussels, Belgium; e-mail: Sebastien.Olive@ sciencesnaturelles.be;

Etienne.Steurbaut@naturalsciences.be

${ }^{2}$ Evolution \& Diversity Dynamics Lab, Department of Geology, Liège University, B18, Boulevard du Rectorat, Sart-Tilman, 4000 Liège, Belgium; e-mail: e.poty@ulg.ac.be

${ }^{3}$ Department of Organismal Biology, Subdepartment of Evolution and Development, Uppsala University, Norbyvägen 18A, 75236 Uppsala, Sweden; e-mail: per.ahlberg@ebc.uu.se ${ }^{4}$ Direction des Collections, UGC de Paléontologie, Muséum national d'Histoire naturelle, CP 38, 57 rue Cuvier, 75231 Paris cedex 05, France; e-mail: pernegre@mnhn.fr ${ }^{5}$ Katholieke Universiteit Leuven, Celestijnenlaan 200E, 3001 Leuven, Belgium ${ }^{6}$ CR2P, UMR 7207 Sorbonne Universités, CNRS/MNHN/UPMC, CP 38, 57 rue Cuvier, 75231 Paris cedex 05, France; e-mail: gclement@mnhn.fr 


\begin{abstract}
The origin of tetrapods is one of the key events in vertebrate history. The oldest tetrapod body fossils are Late Devonian (Frasnian-Famennian) in age, most of them consisting of rare isolated bone elements. Here we describe tetrapod remains from two Famennian localities from Belgium: Strud, in the Province of Namur, and Becco, in the Province of Liège. The newly collected material consists of an isolated complete postorbital, fragments of two maxillae and one putative partial cleithrum, all from Strud, and an almost complete maxilla from Becco. The two incomplete maxillae and cleithrum from Strud, together with the lower jaw previously recorded from this site, closely resemble the genus Ichthyostega, initially described from East Greenland. The postorbital from Strud and the maxilla from Becco do not resemble the genus Ichthyostega. They show several derived anatomical characters allowing their tentative assignment to a whatcheeriid-grade group. The new tetrapod records show that there are at least two tetrapod taxa in Belgium and almost certainly two different tetrapod taxa at Strud. This locality joins the group of Devonian tetrapod-bearing localities yielding more than one tetrapod taxon, confirming that environments favourable to early tetrapod life were often colonized by several tetrapod taxa.
\end{abstract}

Key words: Becco, Famennian, ichthyostegid-like, Strud, tetrapod, whatcheeriid-grade taxon. 
THE origin of tetrapods was one of the key events in the evolution of vertebrates (Janvier 1996; Clack 2012). It gave rise to a major new group of animals that today numbers some 24,000 living species. Whereas early tetrapods from the Devonian were only known by 3 taxa at the beginning of the 1980s (Ichthyostega Säve-Söderbergh, 1932; Acanthostega Jarvik, 1952 and Tulerpeton Lebedev, 1984), their number has significantly increased to reach, to date, thirteen known genera (Table 1).

The Strud quarry ("Strud northern disused quarry" sensu Denayer et al. 2016) is located in the municipality of Gesves (Province of Namur, Belgium, Fig. 1). This sandstone quarry was exploited in the nineteenth century for the construction of houses in the surrounding area. During quarrying, fossils were collected and shown to the Belgian palaeontologist Maximin Lohest from Liège University. Among this material, kept in the palaeontological collections of Liège University ever since, he identified an incomplete lower jaw as belonging to the fish taxon Dendrodus traquairi (Lohest 1888, pl. VIII: 2, 5). In 2004 this lower jaw was reattributed to an Ichthyostega-like tetrapod (Clément et al. 2004) and in 2005, with the help of geologists from Liège University (L. Barchy and J.-M. Marion), the precise location of the Strud quarry was reestablished. This rediscovery gave fresh impetus to fieldwork activities, which have been continuing until now. Strud has yielded an abundant vertebrate fauna composed of actinopterygian, acanthodian, placoderm (Olive 2015; Olive et al. 2015a), and sarcopterygian fishes (Lohest 1888; Leriche 1931; Clément \& Boisvert 2006). An exquisite invertebrate fauna was also recently revealed (Garrouste et al. 2012; Gueriau et al. 2014a, b, 2016; Lagebro et al. 2015) as well as a diversified plant assemblage (Prestianni et al. 2007). The reader is referred to Olive et al. (2015a, table 1) and Gueriau et al. (2016) for an exhaustive updated list of the Strud fossil content. 
The Becco site is situated on a road embankment close to Becco hamlet in the municipality of Theux (Province of Liège). This Famennian vertebrate-bearing locality was recently discovered by geologists of the Liège University (J.-M. Marion and B. Mottequin) and has yielded early seed plants, antiarch, groenlandaspid and phyllolepid placoderms, diplacanthiform acanthodians, as well as actinopterygians, and dipnomorph and tetrapodomorph sarcopterygians (Olive et al. 2015b).

Here we describe new tetrapod remains from the Famennian localities of Strud and Becco and attempt a taxonomical assignation through a comparative study with other well known Devonian and Carboniferous tetrapods. We attempt to assess the number of Devonian tetrapod taxa present in Belgium and examine the problem of evaluating animal diversity based on isolated elements.

Institutional abbreviations. IRSNB, Institut royal des Sciences naturelles de Belgique, Brussels, Belgium; MNHN, Muséum national d'Histoire naturelle, Paris, France; PALULG, Palaeontological collections of the Liège University, Liège, Belgium.

\section{GEOLOGICAL SETTING}

The Strud quarry is located in the Namur-Dinant Basin. Strata at the top of the Strud section, which provided almost all fossils, correspond to the infill sequence of a channel (lithological unit 7 or UL7) in an alluvial plain (Garrouste et al. 2012; Denayer et al. 2016). They belong to the Upper Famennian Evieux Formation and are late Famennian in age (versabiliscornuta 'Rugospora radiata' zone, VCo 'rad' zone, Denayer et al. 2016; Fig. 1). Tetrapod 
remains are extremely scarce in the Strud vertebrate assemblage. After dozens of weeks of excavation, only four isolated remains reliably attributable to tetrapods have been found in addition to the historically collected specimen. These remains have been found in beds B (IRSNB A.0006) and D (IRSNB A.0003-0005 and PALULG 6106) of lithological unit 7 (Fig.1). These beds correspond to the fining upward portion of the stratigraphic sequence. In the following discussion, the "Strud" designation means the uppermost channel of Strud, i.e. the top (UL7) of the Strud northern disused quarry.

The Becco locality belongs to the Theux Tectonic Window. The stratigraphic succession exposed at Becco is reduced and consists mainly of green shaly siltstone belonging to the Crupet Member (Evieux Formation, late Famennian). According to local and regional stratigraphical and sedimentological observations, this facies indicates a fluvial environment and the fossiliferous horizon most likely corresponds to a channel infill (Olive et al. 2015b).

\section{MATERIAL AND METHODS}

The Devonian tetrapod material from Strud includes the following specimens: PALULG 6106: an incomplete lower jaw; IRSNB A.0003 and IRSNB A.004: fragments of right maxillae; IRSNB A.0005: a putative partial cleithrum; IRSNB A.0006: a complete right postorbital. The postorbital has been collected in bed B of lithological unit 7 whereas the other remains come from bed $\mathrm{D}$ in the same unit.

IRSNB A.0007, an almost complete right maxilla, is the only Devonian tetrapod specimen recorded at Becco yet.

PALULG 6106 and IRSNB A.0005 have been mechanically prepared, whereas IRSNB 
A.0003, 0004, 0006 and 0007 have been mechanically and virtually prepared in order to obtain 3D models of the entire specimens. The specimen IRSNB A.0006 has been partially mechanically prepared due to the very fine and fragile marginal regions of the postorbital bone. The virtually prepared specimens have been scanned (Computerized Tomography Scanning) at the AST-RX (Accès Scientifique à la Tomographie à Rayons X) platform of the MNHN, Paris, using the following scanning parameters: voltage $=85 \mathrm{kV}$, current $=260 \mu \mathrm{A}$; for IRSNB A.0003: number of slices $=1964$, voxel size $=0.028 \mathrm{~mm}$; for IRSNB A.0004: number of slices $=$ 740 , voxel size $=0.024 \mathrm{~mm}$; for IRSNB A.0006: number of slices $=1471$, voxel size $=0.023$ $\mathrm{mm}$; for IRSNB A.0007: number of slices $=2400$, voxel size $=0.050 \mathrm{~mm}$. These four specimens have been virtually reconstructed with MIMICS 16.0 (Materialise's Interactive Medical Image Control System) Software (Materialise Inc.; proprietary software at the MNHN, Paris) at the Atelier 3D, Centre de Recherche sur la Paléobiodiversité et les Paléoenvironnements, MNHN, Paris.

\section{DESCRIPTION}

\section{Description of the tetrapod material from the Strud locality}

The right postorbital IRSNB A.0006 (Fig. 2) is quite complete with only the finest distal parts of the posterior and ventral margins missing. The shape is more or less rectangular with the dorsoventral axis longer than the anteroposterior one. A well-developed anterior expansion is present on the dorsal part of the anterior margin. This anterior expansion is most probably a postfrontal process of the postorbital bone and does not seem to be the postfrontal bone fused to the postorbital. The bone is flat, except for the thickened postfrontal process. The orbital margin 
is relatively large with a strong elbow-like outline. The dorsal margin of the bone is sigmoid with a short overlap area for the parietal in its middle part. Thus, the parietal bone seems to slightly overlap the postorbital, at least partially. Another narrow overlap area, supposedly for the squamosal, is discernable on the posteroventral margin. The ornament consists of fine radiating pits and grooves. A long and large groove running dorsoventrally from the centre of the bone is considered as the postorbital sensory canal. In internal view the bone is quite smooth except the postfrontal process, which shows fine more or less aligned ridges.

The lower jaw (PALULG 6106, Fig. 3), described by Lohest (1888) as a fish fragment and reattributed by Clément et al. (2004) to an Ichthyostega-like tetrapod, includes most of the dentary except the anterior and posterior extremities, and the dorsal portions of the postsplenial and the splenial. However the suture between the two latter bones is not discernible. The splenial is strongly twisted mesially. A depressed and smooth oral groove ["sulcus oralis" of Jarvik (1996: 47)] marks the suture between the dentary and infradentaries, as seen in one of the specimens of Ichthyostega figured by Jarvik (1996: pl. 33.1). A putative mandibular canal is identified on PALULG 6106, consisting of large pores, running anteroposteriorly in the middle part of the postsplenial. The position of these aligned pores is similar to that of the partially open sensory canal in Ichthyostega (Jarvik 1996: pls. 32-33). The dentary was most probably narrow all along its length, a condition met in early tetrapods (Ahlberg \& Clack 1998), but its dorsal margin does not seem to form a low crest hiding the tooth stems, as in several Devonian tetrapods. It also seems that small marginal teeth external to the main tooth row, known in Elginerpeton (Ahlberg 1995) and most of lobe-finned fishes, are here absent. The teeth are widely spaced and strongly curved posteriorly. The upper half of the dentary is ornamented with fine pits coarsening into anastomosed ridges ventrally. There is no suggestion of a radiating 
pattern. The internal face of the lower jaw is badly preserved. Part of the coronoid(s) is preserved but no traces of lateral coronoid teeth have been observed. This could be due to the poor preservation of the specimen but more probably to a poorly developed coronoid tooth row.

The fragments (IRSNB A.0003, Fig. 4A-E; IRSNB A.0004, Fig. 4F-G) of two right maxillae were recently collected at the Strud locality. They both suggest a narrow complete maxilla. The lateral surface is uniformly covered with coarse anastomosed ridges and pits. In internal view, there is a well developed and continuous horizontal shelf (palatal shelf), dorsally to the tooth row, which carries the sutural surfaces for the ectopterygoid and/or dermopalatine. The teeth are almost equal in size, laterally flattened and strongly curved posteriorly, and regularly spaced if we consider the preserved teeth and tooth sockets. Marginal teeth external to the main tooth row are not observed on these maxillae fragments.

A putative cleithrum fragment (Fig. $4 \mathrm{H}$ ) is observable in lateral view. The dorsal and ventral extremities are missing. It is elongate and proportionally thin in shape and displays a finely striate surface and a dorsoventral median furrow, as seen in Ichthyostega (Jarvik 1996: pls. 48.1, 51.1). This furrow is located between two broken weakly developed ridges tapering towards the dorsal end of the bone. The ventral part of the bone is badly preserved and the junction with the endoskeletal shoulder girdle is not observable.

\section{Description of the Devonian tetrapod material from the Becco locality}

The isolated right maxilla IRSNB A.0007 (Fig. 5) is almost complete. Due to diaclastic fragmentation of the fossiliferous layer into more or less geometric small blocks, the posterodorsal corner of the maxilla is missing. Adjacent blocks did not provide the missing piece, which must certainly be very small since the posterior end of the bone is preserved. This 
maxilla is a long and narrow tooth-bearing bone. Its anterior tip tapers to form an anterior process with a smooth dorsal surface. This anterior process abutted the posterior margin of the premaxilla and separated the naris (externally) and the choana (medially). The smooth surface, ventrally delimited by a deep groove, was most probably overlapped externally by the anterior tectal and/or the lacrimal. The groove itself probably housed the infraorbital sensory canal. In internal view, the smooth and concave margin of the anterior part of the bone corresponds to the posterolateral margin of the choana. Posteriorly to the anterior process, the bone rapidly deepens to its maximum depth, then gradually becomes shallower towards its posterior tip. The dorsal region of the posterior half of the bone presents externally a long and extended overlap area with thin longitudinal ridges, most probably for the jugal bone. A small, smooth and concave area on the posteroventral end of the maxilla could possibly be the overlap area for the dentary bone of the lower jaw. Internally the medial wall of the posterior end of the maxilla is smooth and slightly concave, forming the most anterior part of the lateral wall of the subtemporal fossa. Teeth and spaces left by missing teeth indicate a total of 23 teeth. Tooth size is linked with the height of the bone. The teeth reach their maximum size on the deepest part of the bone, where two large teeth, with adjacent tooth pits, are present. The deepest point is also the widest in ventral view. The first two teeth (with one adjacent small pit), just ventrally to the naris, are small. The following two teeth (with two adjacent enlarged pits) are dramatically larger. The posterior teeth are then abruptly smaller, to regularly decrease in size until the posterior end of the maxilla. Except for the larger ones, teeth are rounded in cross section at their base, and all are more or less posteriorly curved. All teeth show longitudinal grooves running from one-third of the height from the base, marking the dentine infoldings. The medial surface of the maxilla shows, posterior to the choana, a prominent shelf ("palatal process" of Clack 1994) running 
parallel and dorsal to the tooth row to slowly disappear at the level of the two posteriormost teeth. This shelf was overlapped by the palatine and the ectopterygoid. Posterior to the choana a reduced medial projection could have been in firm contact with the palatine. Laterally the bone is smooth from the anterior tip to the deepest point of the bone. Its ornamentation consists in pits more or less regularly spaced, with drop-like shapes, the tips of the drops being ventrally oriented. The pits are more marked on the posterior half of the deepest part of the bone.

\section{DISCUSSION}

\section{Comparison of the tetrapod remains from Belgium with other Devonian and Carboniferous} tetrapods

Lower jaw and maxillae. The lower jaw from Strud resembles those of other Devonian tetrapods by its narrow dentary. It differs from Acanthostega by its ornament, consisting of pits in Acanthostega (Ahlberg \& Clack 1998) and by the suture separating the dentary from both splenial and postsplenial, which is loose in Acanthostega. If the deep furrow marking the suture between the dentary and the (post?)splenial in Elginerpeton (Ahlberg 1995; Ahlberg \& Clack 1998) is the equivalent of the "oral groove" of PALULG 6106, that could mean that both taxa share this character with Webererpeton and Obruchevichthys (Clément \& Lebedev 2014). The firm attachment of the dentary to the infradentaries is also a shared character between the lower jaw from Strud, Ichthyostega and Elginerpeton. However, Elginerpeton differs by its ornament and the presence of small marginal teeth external to the main tooth row. 
PALULG 6106 resembles the lower jaw of Ventastega (Ahlberg et al. 1994) by the twisted anterior part of the lateral surface but differs by the loose attachment of the dentary to the infradentaries in Ventastega and by the ornament of the dentary, which displays a smooth strip along the ventral margin, in Ventastega.

Densignathus (Daeschler 2000) displays a loose attachment of the dentary to the infradentaries, and the lateral surface is almost devoid of ornament, two characters which were not observed on the lower jaw from Strud.

As already noticed by Clément et al. (2004), PALULG 6106 closely resembles the lower jaw of Ichthyostega by the general shape of the dentary, the dermal ornament, the dentition, and by the firm attachment of the dentary to the splenial and postsplenial (Ahlberg \& Clack 1998). A well-marked oral groove is also present in some Ichthyostega specimens (e.g., Jarvik 1996: pl. 33.1), but this feature is also known in some Frasnian tetrapods (Elginerpeton, Webererpeton, Obruchevichthys).

Clack et al. (2012) described Ymeria, a new Devonian tetrapod genus from East Greenland, very similar to Ichthyostega. Teeth of these two taxa differ by their shape, scarcely curved in Ymeria but clearly posteriorly curved in Ichthyostega, as seen on the lower jaw and maxillae specimens from Strud. The lower jaw of Ymeria is also almost devoid of dermal ornament.

The dentition and ornament of the fragments of maxillae from Strud correspond closely to the lower jaw, suggesting that they represent the same taxon. Like the lower jaw, they resemble the corresponding parts of Ichthyostega (Jarvik 1996: pls.6-7). They differ from Acanthostega (Clack 1994, fig. 2B; Jarvik 1996, fig. 8) by the proportionally larger teeth, and from Ventastega (Ahlberg et al. 1994, fig. 3b) by the relatively coarse ornament dominated by oblique ridges. 
The maxilla from Becco differs substantially from the Strud maxillae in overall morphology, tooth shape and ornament, and evidently represents a separate taxon. Its preservation and completeness suggests that it was loosely attached, with no interdigitating sutures, to all adjacent bones (premaxilla, anterior tectal, lacrimal, jugal, quadratojugal, ectopterygoid, palatine, vomer). This feature is known in Ventastega (Ahlberg et al. 1994) and Acanthostega (Clack 1994).

The maxilla from Becco is proportionally short compared to that of the Devonian tetrapods Acanthostega and Ventastega. The total number of teeth is also much lower, with 23 teeth or tooth pits compared to more than 40 (between 55 and 60 in Ventastega). By contrast its tooth count is close to those of Ichthyostega and Ymeria with a total number of teeth ranging between 16 and 24 (Blom 2005; Clack et al. 2012). Devonian tetrapods lack well-developed teeth on the maxilla, as observed anteriorly on the Becco maxilla. Enlarged teeth are present in Ventastega (Ahlberg et al. 1994), Ymeria (Clack et al. 2012) and Ichthyostega (Jarvik 1996), approximately on the same region of the bone as in the maxilla from Becco, but they are smaller and contrast less sharply with surrounding teeth. The largest teeth of Ymeria lie between positions 3 and 5 . These features, together with the size proportions of the teeth, strongly recall those of the maxilla from Becco. Furthermore, the bones of Ymeria show a poorly defined ornament, although the ornament of the maxilla itself is not clearly obvious. However the dentition of the maxillae of Ymeria and from Becco differ by the gradual size reduction of the teeth from the enlarged ones to the most posterior ones. In Ichthyostega, Acanthostega, and Ventastega, the ornament of the maxilla is composed of coarse pits and anastomosed ridges, and not of small pits or by an absence of ornament as in IRSNB A.0007. 
Early Carboniferous tetrapods Ossinodus from Queensland, Australia (Thulborn et al. 1996; Warren \& Turner 2004; Warren 2007), Pederpes from Scotland (Clack \& Finney 2005) and Whatcheeria from Iowa, USA (Lombard \& Bolt 1995) were all phylogenetically placed in the Whaatcheeriidae (Clack 2002a) but according to later suggestions Whatcheeriidae could be a grade rather than a clade (Warren 2007). The proportion and dentition of the maxilla from Becco are close to those of maxillae of Ossinodus (Thulborn et al. 1996; Warren \& Turner 2004; Warren 2007). The number of tooth loci in the Ossinodus material varies with the length of the maxilla, ranging from 33 to 42 (for a maxilla length respectively of 100 and $145 \mathrm{~mm}$ ). Enlarged teeth are well developed, with 2 to 3 small anterior teeth. The ornament is composed of pits irregularly spaced as in IRSNB A.0007, although the ornament looks coarser in Ossinodus. The maxilla from Becco is however thinner in ventral view and the medial margin of the palatal shelf is not sinusoidal, forming well-marked embayments, as it does in Ossinodus as well as Eogyrinus and Anthracosaurus (Panchen 1972). The maxilla from Becco is also very similar to that of Whatcheeria (Lombard \& Bolt 1995). The latter is relatively short with approximately 33 teeth, including a large fang or fang pairs located in the anterior region of the bone. The Tournaisian (lowermost Carboniferous) taxon Pederpes from Scotland (Clack \& Finney 2005) shows the left maxilla in lateral view and the anterior part of the right maxilla in ventral view. In contrast to the isolated maxilla from Becco, some large pores are present on the lateral surface of the bone in Pederpes. A total number of teeth less than 20 is suggested, with a massive tooth about position 4 to 6 . Enlarged maxillary tusk at about position 5 or 6 is a feature known in the Whatcheeriidae (Clack 2002b) but some colosteid taxa also present this feature (Smithson 1982; Hook 1983).

The proportions of the bone, a total number of teeth less than 25 , enlarged maxillary fangs, abrupt size difference between the maxillary fangs and all other teeth, and ornament absent or 
reduced to pits are characteristics that align the maxilla IRSNB A.0007 with those of the Early Carboniferous tetrapods Ossinodus, Whatcheeria, and to a lesser extent Pederpes. Thus, the isolated maxilla IRSNB A.0007 from Becco is here provisionally referred to a whatcheeriidgrade tetrapod.

Postorbital. Few Devonian tetrapod postorbitals have been described. However, IRSNB A.0006 differs from the postorbital of Ichthyostega (Jarvik 1996), Acanthostega (Jarvik 1952; Clack 2002b; Porro et al. 2015) and an undetermined tetrapod from Russia (PIN 2921/3002, Lebedev \& Clack 1993) by a long and angular orbital margin and by a well-developed ventral extension of the bone.

The postorbital from Strud strongly resembles the postorbital of Pederpes finneyae (Clack \& Finney 2005) by the relative size and shape of the element, as well as the extent and squaredshape of the orbital margin. It resembles also, to a lesser extent, to the postorbital of Whatcheeria deltae (Lombard \& Bolt 1995), even if the postfrontal process and the squared-shape of the orbital margin of the latter seem less developed. Daeschler et al. (2009, fig. 5) figured postorbital bones of some early tetrapods. IRSNB A.0006 is very similar to that of an undetermined tetrapod from Red Hill (Daeschler et al. 2009, fig. 5A, ANSP 21873). The orbital margin displays a long lateral extension in both specimens and the overall elbow-like shape of the bone shows a similar squared posterodorsal corner of the orbit. The open groove of the postorbital sensory canal is located proportionally close to the orbital margin in both specimens. The posterior margin is strongly concave in ANSP 21873 (although its posterodorsal part is mainly missing) but convex in IRSNB A.0006. The dorsal margin of the latter specimen has a sigmoid line whereas it is straight on the postorbital from Red Hill. A narrow overlap area, supposedly for the squamosal, 
is present on the ventral margin of both specimens. The ornament is proportionally finer and covers a larger part of the surface on the postorbital from Strud, including on its postfrontal process. The postorbital from Red Hill (ANSP 21873) was assumed to indicate close relationship with a whatcheeriid-grade tetrapod. We come to the same conclusion here for the postorbital bone from Strud.

Cleithrum. IRSNB A.0005 is badly preserved but could represent an incomplete tetrapod cleithrum. If considered as such, it resembles the cleithrum of Ichthyostega (Jarvik 1996, fig. 42B) by its elongate shape, its slightly striate surface and its dorsoventral median depression. Ichthyostega shows an important diversity in the overall shape and morphology of the cleithra, with a more or less marked dorsoventral depression. However, the ridges surrounding this depression are more clearly developed in IRSNB A.0005 than in all known complete cleithra of Ichthyostega, with the exception of one specimen (Jarvik 1996: pl. 48.1). It differs from the cleithrum of Elginerpeton (Ahlberg 1998) by a narrower cleithrum stem and from the cleithrum of Hynerpeton (Daeschler et al. 1994), Jakubsonia (Lebedev 2004) and Tulerpeton (Lebedev \& Coates 1995) by a more elongate overall shape and by the presence of the dorsoventral median depression on its lateral surface. Cleithra of Ventastega (Ahlberg et al. 2008) and Acanthostega (Coates 1996, fig. 13a) are slender too but differ from IRSNB A.0005 by the absence of the dorsoventral median depression on the lateral surface.

Tetrapod diversity in Belgium 
The task of recognizing a taxonomic diversity among isolated skeletal elements using morphological data always proves to be difficult (Daeschler et al. 2009). The situation of the Devonian tetrapod remains from Belgium is another example highlighting this problem. The Strud locality provided two maxilla fragments, a lower jaw, a putative cleithrum and a postorbital whereas the Becco site yielded a maxilla. The cleithrum is badly preserved, making its identification and taxonomical assignation within tetrapods rather difficult. The two maxilla fragments and the lower jaw from Strud display large and curved teeth and a well-marked ornament, and probably belong to the same taxon. They resemble the Ichthyostega material from East Greenland but are too incomplete to be formally attributable to that genus.

The isolated postorbital bone found in Strud is rather different from that of Ichthyostega and displays whatcheeriid features. We could thus consider either that there are two tetrapod taxa at the Strud locality, one with ichthyostegid and another one with whatcheeriid features, or that all these tetrapod remains from Strud are elements of a single new taxon. Such a case occurred in the past with Ossinodus pueri, a Carboniferous tetrapod of Australia (Warren \& Turner 2004), the material of which was first attributed by Thulborn et al. (1996) to three different taxa (an anthracosaur, a colosteid and a possible temnospondyl).

The almost complete maxilla from the Becco site is different from the maxilla fragments found at Strud. The former shows teeth proportionally smaller (except for the maxillary fangs) and much less curved, and an ornament composed of a restricted area of small pits rather of a network pits and anatomosed ridges. The maxilla IRNSB. A0007 from Becco is very similar to those known in the Early Carboniferous tetrapods of the whatcheeriid group.

The whatcheeriid-like maxilla found in Becco, very different from the Strud maxillae, argues for the presence of a whatcheeriid taxon in Belgium, which could be also represented by 
the postorbital from Strud. Thus, two different tetrapod taxa occurred in the Late Devonian (Famennian) of Belgium and both could be present in the Strud locality.

\section{Devonian tetrapod distribution}

Blieck et al. (2007, 2010) established the biostratigraphical and palaeogeographical framework of early tetrapods. Since that study, new early tetrapod finds have been recorded. The description of Ymeria from East Greenland (Clack et al. 2012) confirmed that this area yielded the greatest number of Devonian tetrapod taxa including three species of Ichthyostega, one species of Acanthostega and one species of Ymeria. Daeschler et al. (2009) demonstrated the presence of at least three early tetrapod taxa in Red Hill (Pennsylvania, USA) including the possible presence of the oldest known whatcheeriid-like tetrapod. Recently, Clément \& Lebedev (2014) included a part of the material of Obruchevichthys gracilis from the Frasnian of Russia in a new taxon called Webererpeton sondalensis on the basis of different lower jaw characters. This brings the total number of Devonian tetrapod genera to 13, plus at least 6 undetermined but putative new tetrapod taxa (Table 1). These recent discoveries confirm that Devonian tetrapods are mainly found in Euramerica. Only two genera have been found outside Euramerica so far, Metaxygnathus denticulus and Sinostega pani, respectively in Australia and China (Campbell \& Bell 1977; Zhu et al. 2002).

With the occurrence of at least two Devonian tetrapod taxa in Wallonia (southeastern part of Belgium) and almost certainly two tetrapod taxa at Strud, this locality joins the group of Devonian tetrapod-bearing localities that have yielded more than one tetrapod taxon (Table 1), i.e. Red Hill in Pennsylvania with at least 3 tetrapod taxa (Daeschler et al. 2009); East Greenland with three genera and five species in Ymer $\varnothing$, and two genera and four species in Gauss Halvø; 
Ketleri in Latvia with two tetrapod genera (Ahlberg et al. 1994); and Andreyevka-2 in Russia with also two tetrapod genera (Lebedev \& Clack 1993). It reinforces the conclusion that, already before the end of the Devonian, environments favourable to early tetrapods were in many cases supporting modestly diversified tetrapod faunas, with members distinguished by morphological characteristics that probably reflect subtly different ecological adaptations. This represents the beginning of a process of tetrapod diversification that has continued through to the present day.

Acknowledgements. We gratefully acknowledge the Belgian Federal Science Policy Office for the research financial support (Doctoral Fellow to S. O.). We thank M. García Sanz at the X-ray Tomography Imagery Platform AST-RX of the UMS2700, MNHN, Paris, France (funded by MNHN, CNRS, Institut de France, Région Ile-de-France) for the X-ray tomography scans. Thanks are also due to F. Goussard and D. Germain (Atelier 3D, UMR 7207 MNHN/CNRS/UPMC) for their help in the 3D modelling process. Nathan Vallée-Gillette (MNHN, Paris) mechanically and virtually prepared IRSNB A.0007. W. Miseur (IRSNB, Brussels) and P. Loubry (MNHN, Paris) took the photographs. A. Folie and A. Dreze (IRSNB, Brussels) granted access to the collection of the IRSNB and provided technical support. J. Denayer (ULg, Liège) granted access to the collection of the ULg. We thank the Gesves local council staff for providing us technical support and excavation permission in Strud. We are indebted to J.-M. Marion and B. Mottequin, who discovered the Becco site and to P. Schmetz, the owner of the site, who authorized excavations. All Strud and Becco fieldworkers are also greatly acknowledged. The authors also thank the editor and reviewers for their fruitful remarks. This paper is a contribution to the ANR TERRES 2010-BLAN-607-03 project. 


\section{REFERENCES}

AHLBERG, P. E. 1991. Tetrapod or near-tetrapod fossils from the Upper Devonian of Scotland. Nature, 354, 298-301. 1995. Elginerpeton pancheni and the earliest tetrapod clade. Nature, 373, 420-425. 1998. Postcranial stem tetrapod remains from the Devonian of Scat Craig, Morayshire, Scotland. Zoological Journal of the Linnean Society, 122, 99-141. and CLACK, J. A. 1998. Lower jaws, lower tetrapods-a review based on the Devonian genus Acanthostega. Transactions of the Royal Society of Edinburgh: Earth Sciences, 89, $11-46$.

LUKSEVICS, E. and LEBEDEV, O. A. 1994. The first tetrapod finds from the Devonian (Upper Famennian) of Latvia. Philosophical Transactions of the Royal Society of London, Series B: Biological Sciences, 343, 303-328.

- BEZNOSOV, P., LUKSEVICS, E. and CLACK, J. A. 2011. A very primitive tetrapod from the earliest Famennian of South Timan, Russia. Presented at the 71st Annual Meeting, Society of Vertebrate Paleontology, Philadelphia, 60.

- CLACK, J. A., LUKSEVICS, E., BLOM, H. and ZUPINS, I. 2008. Ventastega curonica and the origin of tetrapod morphology. Nature, 453, 1199-1204.

ALEKSEEV, A. A., LEBEDEV, O. A., BARSKOV, I. S., BARSKOVA, M. I., KONONOVA, L. I. and CHIZHOVA, V. A. 1994. On the stratigraphic position of the Famennian and Tournaisian fossil vertebrate beds in Andreyevka, Tula Region, Central Russia. Proceedings of the Geologists' Association, 105, 41-52.

BLIECK, A., CLEMENT, G. and STREEL, M. 2010. The biostratigraphical distribution of 
earliest tetrapods (Late Devonian): a revised version with comments on biodiversification. 129-138. In VECOLI, M., CLEMENT, G. and MEYERBERTHAUD, B. (eds). The Terrestrialization Process: Modelling Complex Interactions at the Biosphere-Geosphere Interface. Geological Society Special Publications, London, $192 \mathrm{pp}$.

BLOM, H., LELIEVRE, H., LUKSEVICS, E., STREEL, M., THOREZ, J. and YOUNG, G. C. 2007. The biostratigraphical and palaeogeographical framework of the earliest diversification of tetrapods (Late Devonian). Geological Society, London, Special Publications, 278, 219-235.

BLOM, H. 2005. Taxonomic revision of the Late Devonian tetrapod Ichthyostega from East Greenland. Palaeontology, 48, 111-134.

CLACK, J. A. and AHLBERG, P. E. 2005. Localities, distribution and stratigraphical context of the Late Devonian tetrapods of East Greenland. Meddelelser $\emptyset m$ Grønland: Geoscience, 43, 1-50.

and FRIEDMAN, M. 2007. Devonian vertebrates from East Greenland: a review of faunal composition and distribution. Geodiversitas, 29, 119-141.

CAMPBELL, K. S. W. and BELL, M. W. 1977. A primitive amphibian from the Late Devonian of New South Wales. Alcheringa, 1, 369-381.

CLACK, J. A. 1994. Earliest known tetrapod braincase and the evolution of the stapes and fenestra ovalis. Nature, 369, 392-394. 2002a. An early tetrapod from Romer's Gap. Nature, 418, 72-76. 2002b. The dermal skull roof of Acanthostega gunnari, an early tetrapod from the Late Devonian. Earth and Environmental Science Transactions of the Royal Society of 
Edinburgh, 93, 17-33.

2012. Gaining ground: The Origin and Evolution of Tetrapods. Indiana University Press, Bloomington and Indianapolis, $523 \mathrm{pp}$.

and FINNEY, S. M. 2005. Pederpes finneyae, an articulated tetrapod from the

Tournaisian of Western Scotland. Journal of Systematic Palaeontology, 2, 311-346.

AHLBERG, P. E., BLOM, H. and FINNEY, S. M. 2012. A new genus of Devonian

tetrapod from North-East Greenland, with new information on the lower jaw of

Ichthyostega. Palaeontology, 55, 73-86.

CLEMENT, G. and BOISVERT, C. A. 2006. Lohest's true and false "Devonian amphibians":

evidence for the rhynchodipterid lungfish Soederberghia in the Famennian of Belgium.

Journal of Vertebrate Paleontology, 26, 276-283.

and LEBEDEV, O. A. 2014. Revision of the early tetrapod Obruchevichthys Vorobyeva, 1977 from the Frasnian (Upper Devonian) of the North-western East European Platform.

Paleontological Journal, 48, 1082-1091.

AHLBERG, P. E., BLIECK, A., BLOM, H., CLACK, J. A., POTY, E., THOREZ, J. and

JANVIER, P. 2004. Palaeogeography: Devonian tetrapod from Western Europe. Nature, 427, 412-413.

COATES, M. I. 1996. The Devonian tetrapod Acanthostega gunnari Jarvik: postcranial anatomy, basal tetrapod interrelationships and patterns of skeletal evolution. Transactions of the Royal Society of Edinburgh: Earth Sciences, 87, 363-421.

CRESSLER, W. L., DAESCHLER, E. B., SLINGERLAND, R. and PETERSON, D. A. 2010. Terrestrialization in the Late Devonian: a palaeoecological overview of the Red Hill site, Pennsylvania, USA. 111-128. In VECOLI, M., CLÉMENT, G. and MEYER- 
BERTHAUD, B. (eds). The Terrestrialization Process: Modelling Complex Interactions at the Biosphere-Geosphere Interface. Geological Society, London, 192 pp.

DAESCHLER, E. B. 2000. Early tetrapod jaws from the Late Devonian of Pennsylvania, USA. Journal of Paleontology, 74, 301-308. and CRESSLER, W. L. 2011. Late Devonian paleontology and paleoenvironments at Red Hill and other fossil sites in the Catskill Formation of north-central Pennsylvania. Geological Society of America Field Guide, 20, 1-16.

CLACK, J. A. and SHUBIN, N. H. 2009. Late Devonian tetrapod remains from Red Hill, Pennsylvania, USA: how much diversity? Acta Zoologica, 90, 306-317. SHUBIN, N. H., THOMSON, K. S. and AMARAL, W. W. 1994. A Devonian tetrapod from North America. Science, 265, 639-642.

DENAYER, J., PRESTIANNI, C., GUERIAU, P., OLIVE, S. and CLÉMENT, G. 2016. Stratigraphy and depositional environments of the Late Famennian (Late Devonian) of Southern Belgium and characterization of the Strud locality. Geological Magazine, 153, $112-127$.

ESIN, D., GINTER, M., IVANOV, A., LEBEDEV, O. A., LUKSEVICS, E., AVKHIMOVICH, V., GOLUBTSOV, V. and PETUKHOVA, L. 2000. Vertebrate correlation of the upper Devonian and lower Carboniferous on the east European platform. Courier Forschungsinstitut Senckenberg, 223, 341-359.

GARROUSTE, R., CLÉMENT, G., NEL, P., ENGEL, M. S., GRANDCOLAS, P., D’ HAESE, C., LAGEBRO, L., DENAYER, J., GUERIAU, P., LAFAITE, P., OLIVE, S., PRESTIANNI, C. and NEL, A. 2012. A complete insect from the Late Devonian. Nature, $488,82-85$. 
GUERIAU, P., CHARBONNIER, S. and CLÉMENT, G. 2014a. First decapod crustaceans in a Late Devonian continental ecosystem. Palaeontology, 57, 1203-1213. 2014b. Angustidontid crustaceans from the Late Devonian of Strud (Namur Province, Belgium): insights into the origin of Decapoda. Neues Jahrbuch für Geologie and Paläontologie, Abhandlungen, 273/3, 327-337.

RABET, N., CLEMENT, G., LAGEBRO, L., VANNIER, J., BRIGGS, D. E. G., CHARBONNIER, S., OLIVE, S. and BETHOUX, O. 2016. A 365-million-year-old freshwater community reveals morphological and ecological stasis in branchiopod crustaceans. Current Biology, 26, 383-390.

HOOK, R. W. 1983. Colosteus scutellatus (Newberry), a primitive temnospondyl amphibian from the Middle Pennsylvanian of Linton, Ohio. American Museum Novitates, 2770, 141.

JANVIER, P. 1996. Early Vertebrates. Clarendon Press, Oxford. 393 pp.

JARVIK, E. 1952. On the fish-like tail in the ichthyostegid stegocephalians. Meddelelser $\not m$ Grønland, 114, 1-90. 1996. The Devonian tetrapod Ichthyostega. Fossils \& Strata, 40, 1-213.

LAGEBRO, L., GUERIAU, P., HEGNA, T. A., RABET, N., BUTLER, A. and BUDD, G. E. 2015. The oldest notostracan (Upper Devonian Strud locality, Belgium). Palaeontology, 58, 497-509

LEBEDEV, O. A. 1984. The first find of a Devonian tetrapod in the USSR. Doklady Akademii Nauk SSSR, 278, 1470-1473.

2004. A new tetrapod Jakubsonia livnensis from the Early Famennian (Devonian) of Russia and palaeoecological remarks on the Late Devonian tetrapod habitats. Acta 
Universitas Tatviensis, 679, 79-98.

and CLACK, J. A. 1993. Upper Devonian tetrapods from Andreyevka, Tula region,

Russia. Palaeontology, 36, 721-734.

and COATES, M. I. 1995. The postcranial skeleton of the Devonian tetrapod Tulerpeton curtum Lebedev. Zoological Journal of the Linnean Society, 114, 307-348.

LERICHE, M. 1931. Les poissons famenniens de la Belgique - Les faciès du Famennien dans la région gallo-belge - Les relations entre les formations marines et les formations continentales du Dévonien supérieur sur la bordure méridionale du continent NordAtlantique. Mémoires de la Classe des Sciences de l'Académie Royale de Belgique, 4, 172.

LOHEST, M. 1888. Recherche sur les poissons des terrains paléozoïques de Belgique. Poissons des Psammites du Condroz, Famennian supérieur. Annales de la Société géologique de Belgique, 15, 112-203.

LOMBARD, R. E. and BOLT, J. R. 1995. A new primitive tetrapod, Whatcheeria deltae, from the Lower Carboniferous of Iowa. Palaeontology, 38, 471-494.

LUKSEVICS, E. and ZUPINS, I. 2003. Taphonomic studies of the Devonian fish and tetrapod fossils from the Pavari site (Latvia). 37-38. In SCHULTZE, H.-P., LUKSEVICS, E. and UNWIN, D. (eds). The Gross Symposium 2: Advances in Palaeoichthyology \& IGCP 491 meeting (Riga, Latvia, 8-14 Sept. 2003). Ichthyolith Issues Special Publication, Latvia. 2004. Sedimentology, fauna, and taphonomy of the Pavāri site, Late Devonian of Latvia. Acta Universitatis Latviensis, 679, 99-119. - BEZNOSOV, P. A., MAJDL, T. V., AHLBERG, P. E. and STINKULIS, G. 2010.

Taphonomy of a Late Devonian vertebrate assemblage from Izhma River site, 
Sosnogorsk Formation, South Timan, Russia. Presented at the third International Palaeontological Congress, London, 255.

OLIVE, S. 2015. Devonian antiarch placoderms from Belgium revisited. Acta Palaeontologica Polonica, 60, 711-731.

CLEMENT, G., DAESCHLER, E. B. and DUPRET, V. 2015a. Characterization of the placoderm (Gnathostomata) assemblage from the tetrapod-bearing locality of Strud (Belgium, Upper Famennian). Palaeontology, 58, 981-1002. - DENAYER, J., DERYCKE, C., DUPRET, V., GERRIENNE, P., GUERIAU, P., MARION, J.-M., MOTTEQUIN, B. and PRESTIANNI, C. 2015b. Flora and fauna from a new Famennian (Upper Devonian) locality at Becco, eastern Belgium. Geologica Belgica, 18, 92-101.

PAN, J., HUO, F. C., CAO, J.X., GU, Q. C., LIU, S. Y., WANG, J. Q., GAO, L. D. and LIU, C. 1987. Continental Devonian System of Ningxia and its biotas. Geological Publishing House. Beijing. 237 pp. [in Chinese].

PANCHEN, A. L. 1972. The skull and skeleton of Eogyrinus attheyi Watson (Amphibia: Labyrinthodontia). Philosophical Transactions of the Royal Society of London, Series B, 263, 279-326.

PORRO, L. B., RAYFIELD, E. J. and CLACK, J. A. 2015. Descriptive anatomy and threedimensional reconstruction of the skull of the early tetrapod Acanthostega gunnari Jarvik, 1952. PLOS ONE, 10, e0118882.

PRESTIANNI, C., STREEL, M., THOREZ, J. and GERRIENNE, P. 2007. Strud: old quarry, new discoveries. Preliminary report. 43-47. In STEEMANS, P. and JAVAUX, E. (eds). Recent advances in palynology. Carnet de Géologie, Brest, Memoir 2007/01, 73 pp. 
RITCHIE, A., WANG, S. T., YOUNG, G. C. and ZHANG, G. R. 1992. The Sinolepidae, a family of antiarchs (placoderm fishes) from the Devonian of South China and eastern Australia. Records of the Australian Museum, 44, 319-370.

SAVE-SODERBERGH, G. 1932. Preliminary note on Devonian stegocephalians from East Greenland. Meddelelser фm Grфnland, 94, 1-211.

SMITHSON, T. R. 1982. The cranial morphology of Greererpeton burkemorani Romer (Amphibia: Temnospondyli). Zoological Journal of the Linnean Society, 76, 29-90.

SOROKIN, V. S. 1978. Stages of development of the north-western part of the Russian platform in the Frasnian. Zinatne, Riga. 282 pp. [in Russian].

THULBORN, R. A., WARREN, A. A., TURNER, S. and HAMLEY, T. 1996. Early Carboniferous tetrapods in Australia. Nature, 381, 777-780.

TREWIN, N. H. 2002. The geology of Scotland (4th edition). The Geological Society, London.

VOROBYEVA, E. I. 1977. Morphology and nature of evolution of crossopterygian fishes. Akademia Nauk SSSR, Trudy Paleontologischeskogo Instituta, 163, 1-239.

WARREN, A. 2007. New data on Ossinodus pueri, a stem tetrapod from the Early Carboniferous of Australia. Journal of Vertebrate Paleontology, 27, 850-862. and TURNER, S. 2004. The first stem tetrapod from the Lower Carboniferous of Gondwana. Palaeontology, 47, 151-184.

YOUNG, G. C. 1993. Middle Palaeozoic macrovertebrate biostratigraphy of eastern Gondwana, 208-251. In LONG, J. A. (ed.). Palaeozoic Vertebrate Biostratigraphy and Biogeography. Belhaven Press, London. 369 pp. 1996. Devonian (chart 4). 96-109. In YOUNG G. C. and LAURIE J. R. (eds). An Australian Phanerozoic Timescale. AGSO/Oxford University Press, Melbourne. 
1999. Preliminary report on the biostratigraphy of new placoderm discoveries in the

Hervey Group (Upper Devonian) of central New South Wales. Records of the Western Australian Museum, Supplement, 57, 139-150.

2006. Biostratigraphic and biogeographic context for tetrapod origins during the

Devonian: Australian evidence. Alcheringa: An Australasian Journal of Palaeontology,

30, 409-428.

SHERWIN, L. and RAYMOND, O. L. 2000. Late Devonian: Hervey Group. 125-149.

In LYONS, P., RAYMOND, O. L. and DUGGAN, M. B. (eds). Explanatory NoteForbes 1:250,000 Geological Sheet S155-7, 2nd Edition. AGSO Record.

ZHU, M., AHLBERG, P. E., ZHAO, W. and JIA, L. 2002. First Devonian tetrapod from Asia. Nature, 420, 760-761. 


\section{FIGURE CAPTIONS}

FIG. 1. Location of Strud and Becco in Belgium and stratigraphic position of Strud (Strud paleochannel, lithological unit 7). A, location of Belgium in Europe. B, location of Strud and Becco in Belgium. C, stratigraphic position of Strud. D, lithological and lithostratigraphical column of the Strud paleo-channel. Abbreviations: Cit. De Huy, Citadelle de Huy; Fm, Formation; Lux, Luxemburg; Mbr, Member; Uppermost Fam, Uppermost Famennian. Modified after Denayer et al., 2016. Colour online. [planned for $2 / 3$ page]

FIG. 2. Whatcheeriid-like tetrapod from Strud. IRSNB A.0006, right postorbital. A. photograph, external view. B. 3D reconstruction, external view. C. 3D reconstruction, internal view. Abbreviations: oa.pa, overlap area for the parietal; ?oa.sq, overlap area for the squamosal; orb, orbit; pf.p, postfrontal process of the postorbital; pto.sc, postorbital sensory canal. Black arrows point anteriorly. Scale bars equal $1 \mathrm{~cm}$. Colour online. [planned for page width]

FIG. 3. Ichthyostegid-like tetrapod from Strud. PALULG 6106, partial right lower jaw. A. photograph, lateral view. B. photograph, internal view. Abbreviations: co, coronoid; de, dentary; ?m.c, ?mandibular canal; o.g, oral groove; p.sp, postsplenial; sp, splenial. Black arrows point anteriorly. Scale bars equal $1 \mathrm{~cm}$. Colour online. [planned for page width]

FIG. 4. Ichthyostegid-like tetrapod from Strud. A. IRSNB A.0003, 3D reconstruction, fragment of right maxilla in lateral view. B. IRSNB A.0003, 3D reconstruction, internal view. C. IRSNB A.0003, 3D reconstruction, posterior view. D. IRSNB A.0003, 3D reconstruction, ventral view. 
E. IRSNB A.0003, ventrolateral view. F. IRSNB A.0004, 3D reconstruction, fragment of right maxilla in internal and posteromedial view. G. IRSNB A.0004, 3D reconstruction, ventral view. H. IRSNB A.0005, photograph, partial ?cleithrum in lateral view. Abbreviations: fu, dorsoventral furrow of the ?cleithrum; pa.sh, palatal shelf; t.s, tooth socket. Black arrows point anteriorly. Scale bars equal $1 \mathrm{~cm}$. Colour online. [planned for page width]

FIG. 5. Whatcheeriid-like tetrapod from Becco. IRSNB A.0007, right almost complete maxilla. A. photograph, lateral view. B. photograph, close-up of the anterior part, from the boxed area in (A). C. 3D reconstruction, internal view. D. 3D reconstruction, ventral view. Abbreviations: aw.sf, anterolateral wall of the subtemporal fossa; io.g, groove for infraorbital sensory canal; oa.at/la: overlap area for the anterior tectal and/or lacrimal; ?oa.de, ?overlap area for the dentary; oa.ju, overlap area for the jugal; pa.sh, palatal shelf; pw.ch, posterolateral wall of the choana; ?s.pal: ?suture with the palatine; t.s, tooth socket. Dashed lines indicate the broken posterodorsal margin of the bone. Black arrows point anteriorly. Scale bars equal $1 \mathrm{~cm}$. Colour online. [planned for page width]

TABLE 1. Devonian tetrapod localities of the world with their formations, ages and environments. Updated from Blieck et al., 2007. [planned for portrait page height] 


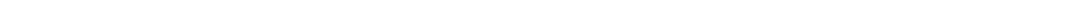



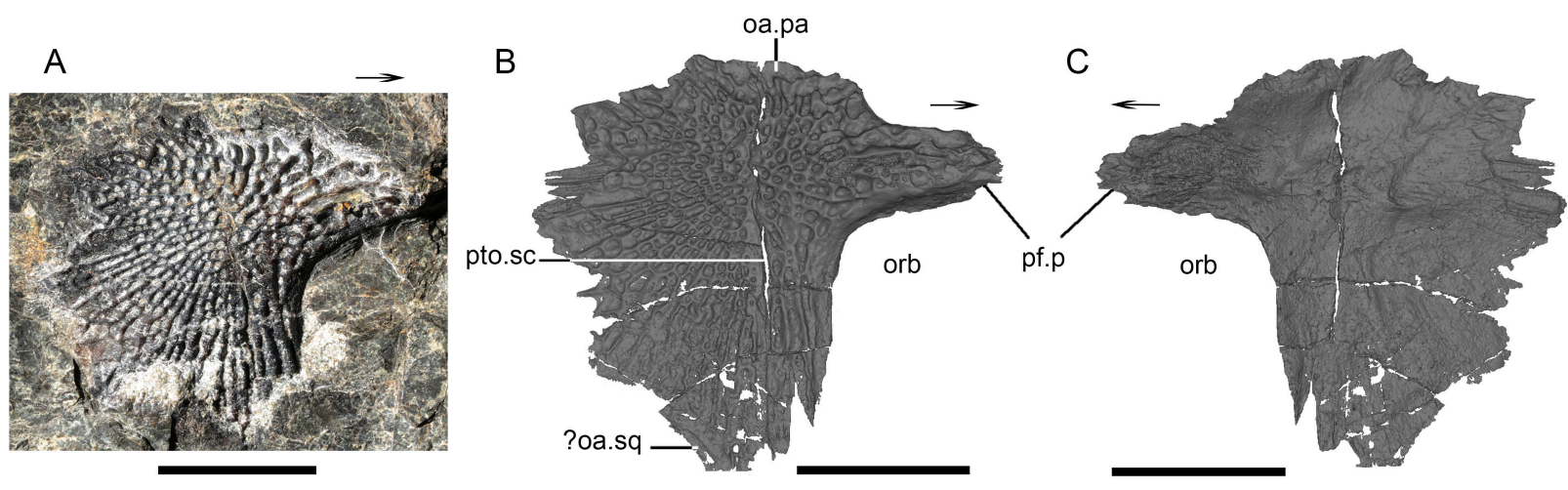

Fig. 2 
A
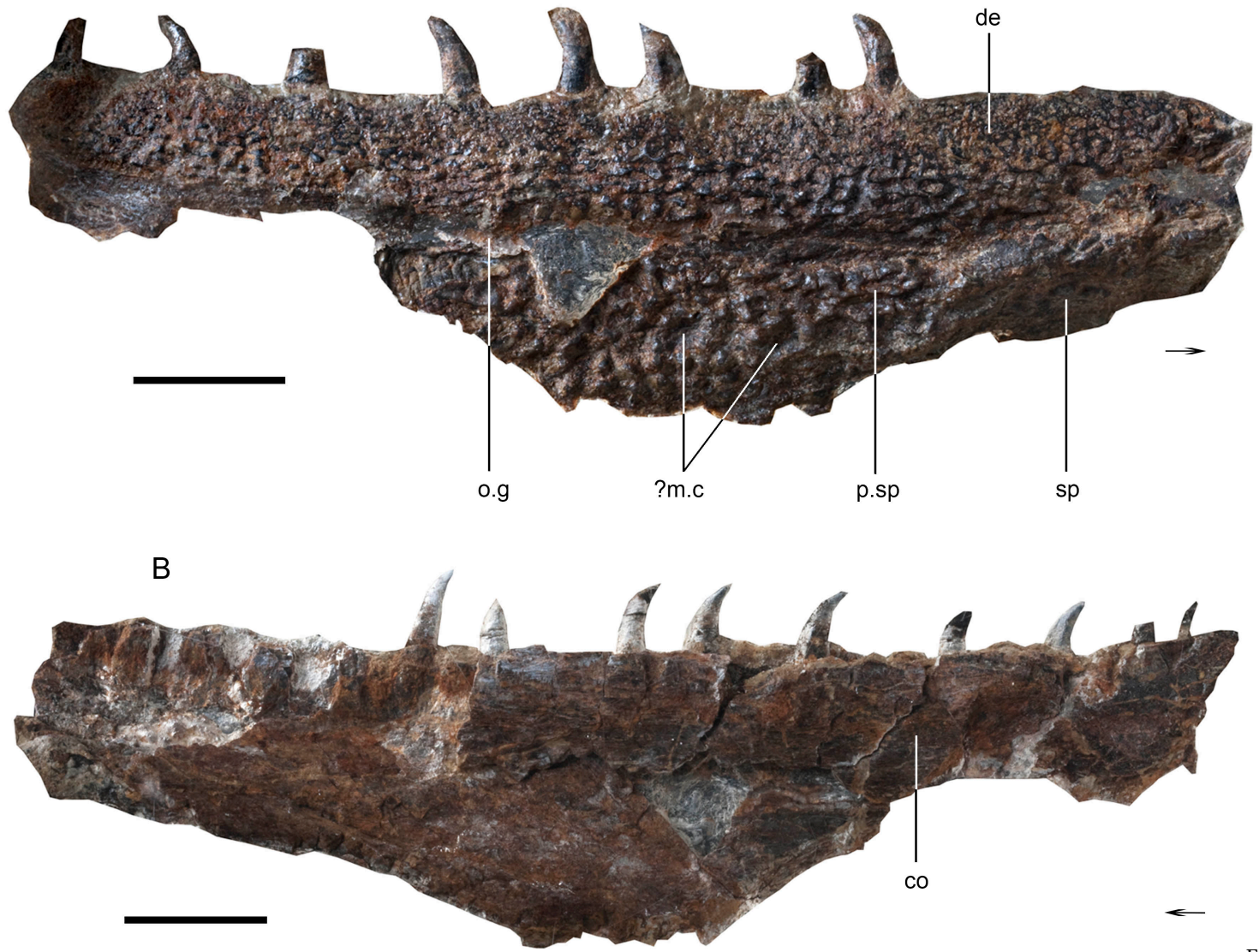
A

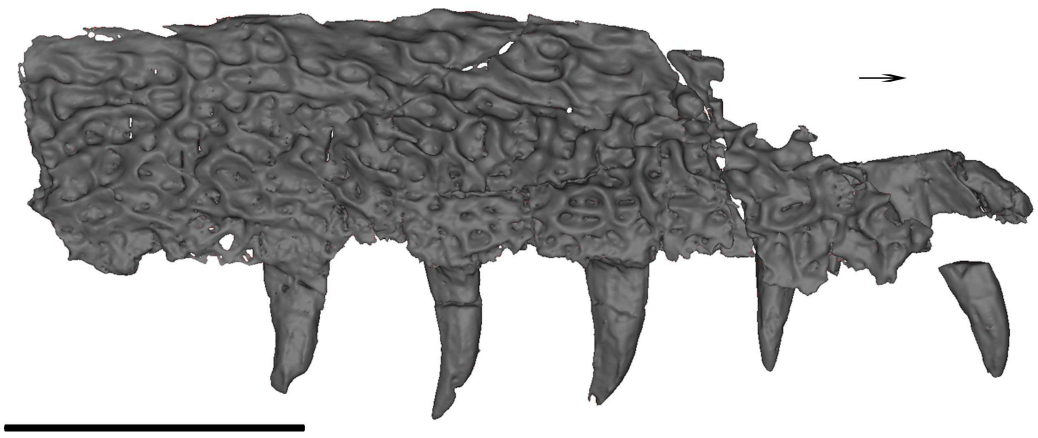

B

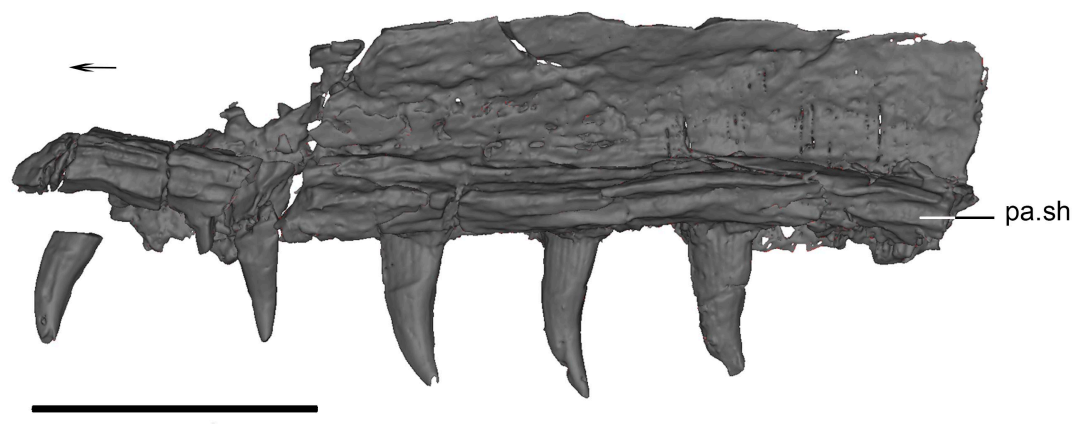

D

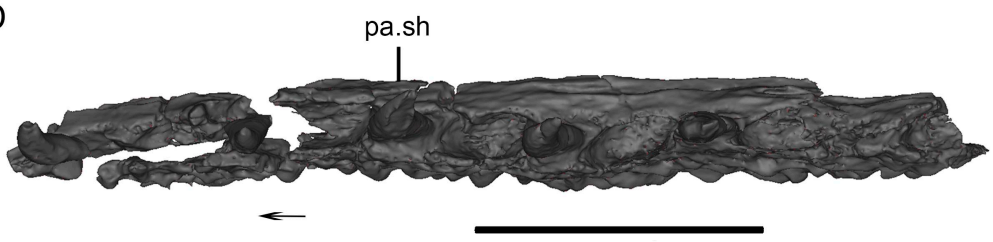

E
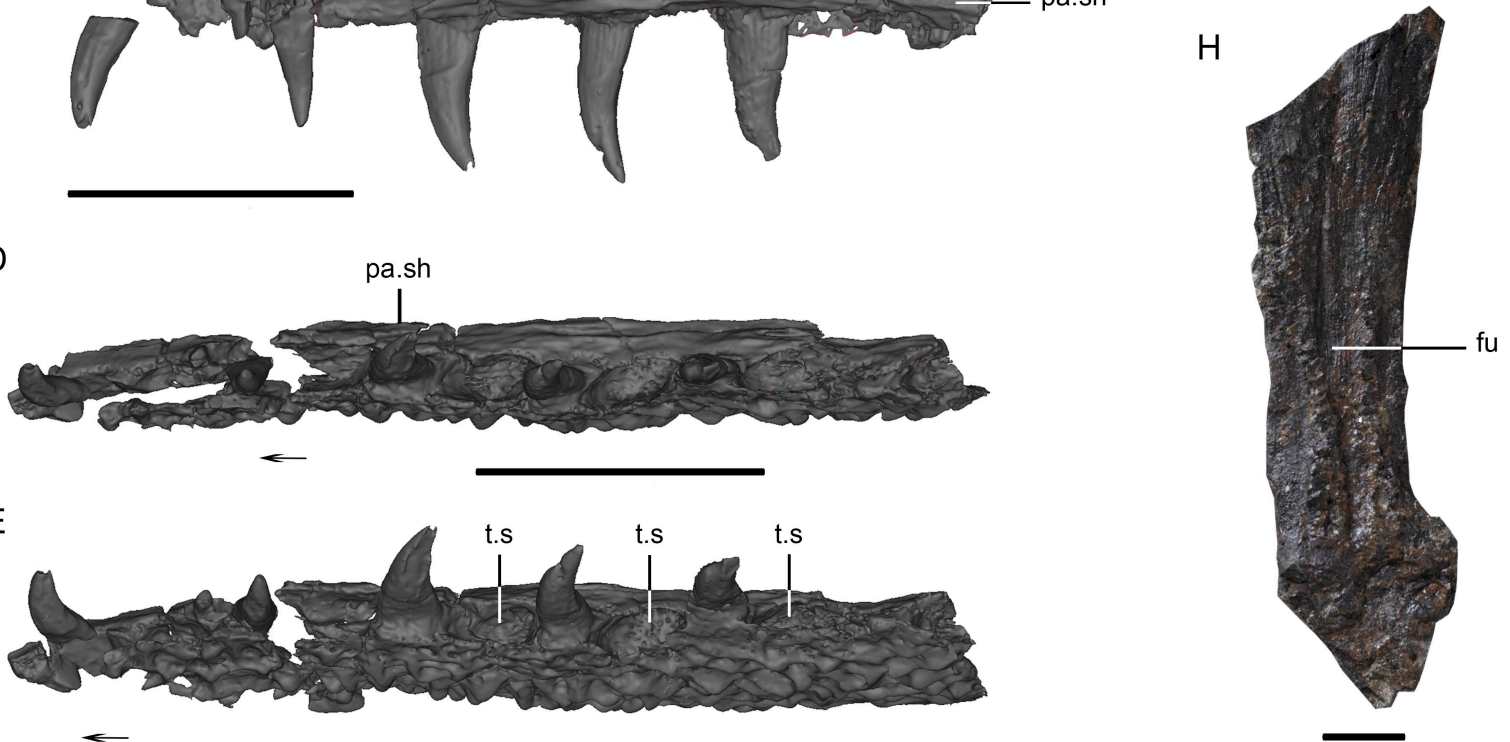

F
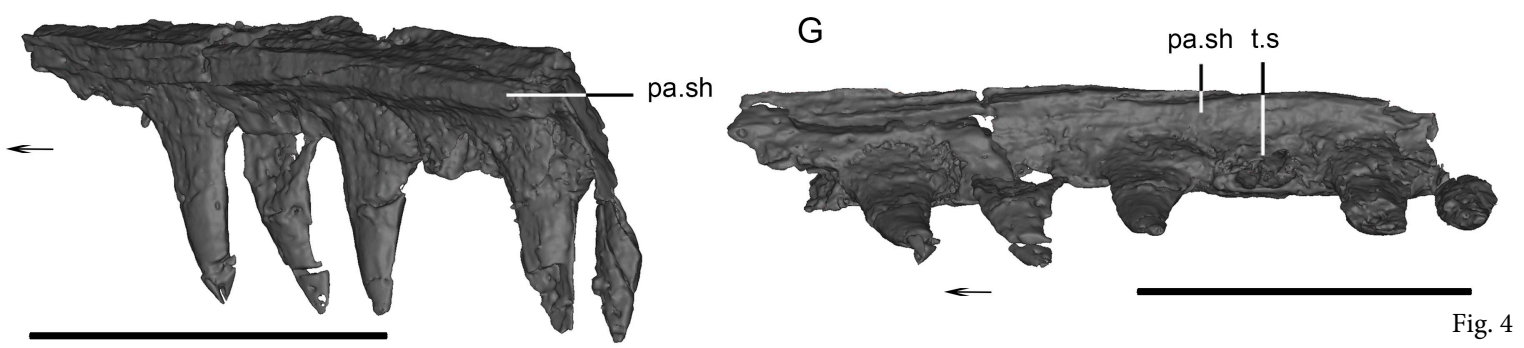
A

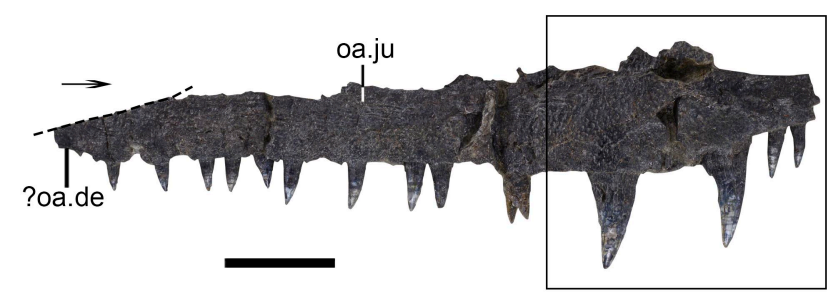

B

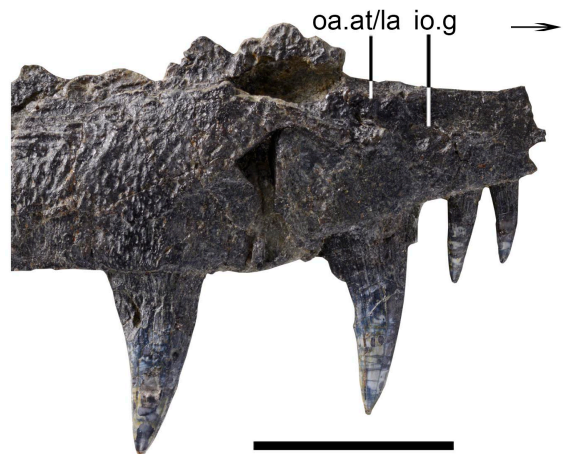

D

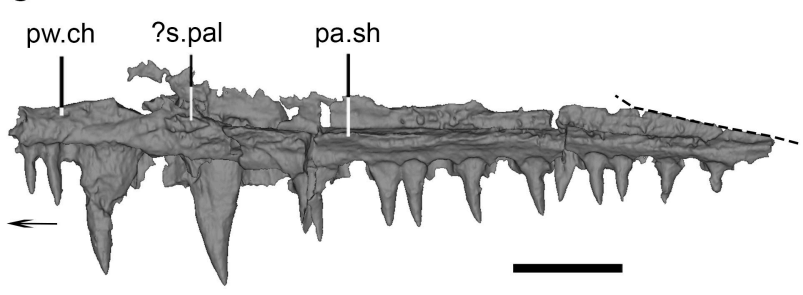

pw.ch

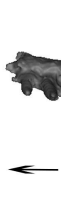

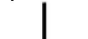

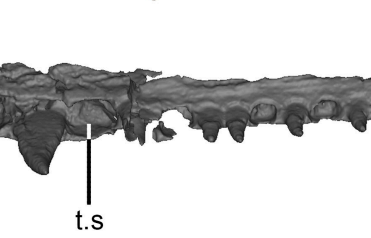

aw.sf

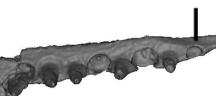

